Cita: Atienza, F.; Appleton, P; Hall, H. K.; Castillo, I.; Balaguer, I. (2020). Validation of the Spanish version of multidimensional inventory of perfectionism in young footballers. Cuadernos de Psicología del Deporte, 20(1), 118-129

\title{
Validation of the Spanish version of multidimensional inventory of perfectionism in young footballers
}

\section{Validación de la versión española del inventario multidimensional de perfeccionismo en jóvenes futbolistas}

\section{Validação da versão em espanhol do inventário multidimensional do perfeccionismo em jovens futebolistas}

\author{
Atienza, F. ${ }^{1}$, Appleton, P. ${ }^{2}$, Hall, H. K. ${ }^{3}$, Castillo, I. ${ }^{1}$, Balaguer, I. ${ }^{1}$ \\ ${ }^{1}$ Faculty of Psychology, University of Valencia; ${ }^{2}$ School of Sport, Exercise and Rehabilitation Sciences, \\ University of Birmingham; ${ }^{3}$ Sutton on the Forest UK
}

\begin{abstract}
The Multidimensional Inventory of Perfectionism in Sport (MIPS) is one sport specific measure of perfectionism developed on the basis of a combination of different multidimensional models. This study assesses the psychometrics of the MIPS in a Spanish sample of young footballers. Participants were 429 Spanish football players with ages ranging from 9 to 13 years. Confirmatory factor analyses showed that a two-dimensional model obtained adequate fit indices and Cronbach's alpha coefficients showed acceptable levels of internal reliability. The criterion and convergent validity of the Spanish MIPS analysed in young footballers was also confirmed via its association with measures of sport anxiety, contingent self-worth and additional perfectionism dimensions. The results of this study suggest that the Spanish version of the MIPS to be used with young footballers is a well-adapted and adequate, reliable and valid sport specific instrument.
\end{abstract}

Key words: Validity; reliability; adolescents; MIPS.

\section{RESUMEN}

El Inventario Multidimensional de Perfeccionismo en Deporte (MIPS) es una medida deportiva específica del perfeccionismo desarrollado a partir de una combinación de diferentes modelos multidimensionales. Este estudio analiza las propiedades psicométricas del MIPS en una muestra española de jóvenes futbolistas. Participaron 429 futbolistas españoles con edades comprendidas entre 9 y 13 años. Los análisis factoriales confirmatorios mostraron que un modelo bidimensional obtenía adecuados índices de ajuste y los coeficientes alfa de Cronbach mostraron niveles de fiabilidad interna aceptables. La validez criterial y convergente del MIPS español estudiada con adolescentes futbolistas ha sido confirmada analizando su asociación con medidas de ansiedad competitiva, autoestima contingente y con otras dimensiones de perfeccionismo. Los resultados de este estudio sugieren que la versión española del MIPS validada para aplicarse a jóvenes futbolistas es un instrumento específico y adecuado para deporte, bien adaptado, fiable y válido.

Palabras clave: validez; fiabilidad; adolescentes; MIPS. 


\section{Validation of Spanish MIPS in young footballers}

\section{RESUMO}

O Inventário Multidimensional do Perfeccionismo no Esporte (MIPS) é uma medida esportiva específica do perfeccionismo desenvolvida a partir de uma combinação de diferentes modelos multidimensionais. Este estudo analisa as propriedades psicométricas do MIPS em uma amostra espanhola de jovens jogadores de futebol. Participaram 429 jogadores de futebol espanhol, com idades entre 9 e 13 anos. A análise fatorial confirmatória mostrou que um modelo bidimensional obteve taxas de ajuste adequadas e os coeficientes alfa de Cronbach mostraram níveis aceitáveis de confiabilidade interna. A validade de critério e convergente dos MIPS espanhóis estudados com jogadores de futebol juvenil foi confirmada pela análise de sua associação com medidas de ansiedade competitiva, autoestima contingente e outras dimensões do perfeccionismo. Os resultados deste estudo sugerem que a versão em espanhol do MIPS validada para aplicação em jovens jogadores de futebol é um instrumento específico e adequado ao esporte, bem adaptado, confiável e válido.

Palavras chave: validade; confiabilidade; adolescentes; MIPS

\section{INTRODUCTION}

Perfectionism is considered to be much more than a commitment to excellence and the sustained pursuit of exceedingly high standards. It is a complex personality characteristic that reflects a distorted and often irrational way of processing achievement information, and which underpins compulsive striving for flawlessness (Flett and Hewitt, 2002). While various models of perfectionism (e.g., Frost, Marten, Lahart and Rosenblate, 1990; Hewitt and Flett, 1991; Hill et al., 2004; Terry-Short, Owens, Slade and Dewey, 1995; Slaney, Rice, Mobley, Trippi and Ashby, 2001; Stoeber, 2011) have emerged in the sporting literature, most researchers agree that perfectionism is multidimensional (Hill and Curran, 2016; Madigan, Stoeberg and Passfield, 2017). Moreover, some authors have proposed a hierarchical structure, comprising two higher-order dimensions labelled perfectionistic strivings and perfectionistic concerns. The dimension of perfectionistic strivings represents striving for perfection and high personal standards for performance. In contrast, the dimension of perfectionistic concerns represents concerns over making mistakes, negative reactions to imperfection, and fears about failing to meet others' high expectations. The two dimensions broadly reflect either the energising or the critical, self-evaluative components of the construct, and because of this, each has a tendency to demonstrate a different pattern of association with a range of cognitive, affective and behavioural outcomes (González-Hernández, Capilla and Gómez-López, 2019; Haraldsen, Halvari, Solstad, Abrahamsen and Nordin-Bates, 2019; Stoeber and Otto, 2006). Whereas perfectionistic strivings are often associated with adaptive processes and outcomes, the dimension of perfectionistic concerns is consistently associated with maladaptive processes and outcomes (Madigan et al., 2017). In a recent review and reanalysis of existing evidence into perfectionism in sport, exercise, and dance, Hill, Mallinson-Howard, Madigan and Jowett (2019) concluded that perfectionistic strivings dimension is complex and ambiguous and that "this dimension (PS) would be unambiguously adaptive for athletes, dancers, and exercisers if it was not correlated with PC, but it typically is" (p.29).

Each model of multidimensional perfectionism, which has guided sport research, has adopted its own separate measurement methodology (e.g., Frost et al., 1990; Hewitt and Flett, 1991; Hill et al., 2004; Terry-Short et al., 1995; Slaney et al., 2001). The consequence of this has been the emergence of numerous subscales, which all purport to measure the various dimensions of the perfectionism construct.

Because there is growing evidence to suggest that perfectionism is a domain-specific construct (Dunn, Gotwals and Dunn, 2005; Mautz, Hill, Hueslman and Bazzini, 2017) that tends to manifest differently across contexts, sport researchers have developed their own sport specific measures which are informed by different multidimensional models of perfectionism (Stoeber and Madigan, 2016). One sport specific instrument that has been developed is the Multidimensional Inventory of Perfectionism in Sports (MIPS; Stoeber, Otto and Stoll, 2004). This instrument that was developed in German and validated for use in both German and English languages, is based on a combination of different multidimensional models (Frost et al., 1990; Hewitt 


\section{Atienza, Appleton, Hall, Castillo, Balaguer}

and Flett, 1991) and the two-factor model described earlier, which suggests that perfectionism has two basic forms: a negative form and a positive form (Stoeber and Otto, 2006). While the original version of the MIPS comprised nine subscales, previous research employing the MIPS with athletes (e.g., Stoeber, Otto, Pesheck, Becker and Stoll, 2007) administered a 10-item scale comprising two 5-item subscales that reflected striving for perfection (SP) and negative reactions to imperfection (NRI). Stoeber and Madigan (2016) report that structural equation modelling has shown these two dimensions to be reliable indicators of perfectionistic strivings and perfectionistic concerns. During the initial validation of the MIPS, the underlying factor structure was supported through the use of exploratory factor analysis (Stoeber et al., 2007). More recently, Madigan (2016) has employed a confirmatory factor analysis and demonstrated that the factorial validity of the MIPS was acceptable in a sample of University athletes. As in other languages, the MIPS has been also validated in Spanish language, specifically, with elite athletes ( $M$ age $=23.3$ years; $S D=5.62)$ representing several Latino American countries that participate in Central American and Caribbean games (PinedaEspejel, Alarcón, López-Valle and Tomás, 2017). Pineda-Espejel and his colleagues analysed the factorial structure, factorial invariance by gender and type of sport, and the validity based on the relationship with precompetitive anxiety. The results confirmed the two-factor structure of MIPS, the structural equivalence and partial invariance of factor loadings of the MIPS across sex and individual vs. collective sports, but not invariance of intercepts. Although the MIPS has been used previously with young athletes (e.g., Madigan, Stoeber and Passfield, 2016; Stoeber, Stoll, Salmi and Tiikkaja, 2009), the psychometrics of the scale in those sample, to our knowledge, have not yet being examined in any language. Hence, filling this gap was the initial interest of this work.

The sports psychologist has a long history in Spanish football and the interest in psychological work in football has been present in Spain since the late 1980s until today (García-Naveira, 2018; Peris, 2018). Together, three were the objectives of the present study. First, to adapt the Multidimensional Inventory of Perfectionism in Sport (Stoeber et al., 2007) items to be used with young Spanish footballers and to examine the factor structure and internal reliability of the instrument in a young adolescent sample and in a collective sport such as football. A second purpose of the present investigation was to ascertain the criterion related validity of the Spanish version of the MIPS in young footballers, by examining the associations between striving for perfection and negative reactions to imperfection with sport anxiety and contingent selfworth. Based on previous studies that have employed the MIPS in sport (e.g., Gotwals, Stoeber, Dunn and Stoll, 2012), it was hypothesized that negative reactions to imperfection and striving for perfection would show a positive relationship with both outcome variables, but that overlap between the two MIPS subscales would inflate the positive relationships between striving for perfection and maladaptive characteristics. Finally, in the conclusions to a recent paper, Madigan (2016) recommended that when undertaking further validation work on the MIPS researchers should examine the convergent validity of the instrument. Consequently, a third purpose of the present investigation was to determine the convergent validity by examining the association between the two subscales captured by the Spanish MIPS in young footballers and other perfectionism dimensions (i.e., self-oriented and socially prescribed perfectionism).

\section{MATERIALS AND METHODS}

\section{Participants}

A subsample of Spanish participants from the larger PAPA project (Promoting Adolescent Physical Activity; Duda et al., 2013) recruited to take part in this study was composed by 429 young football players $(M$ age $=11.48$ years; $S D=1.12$ years; range $=9-13$ years $)(87.8 \%$ males, $12.2 \%$ females $)$ representing 17 different football club schools from the Valencian Football Federation. Design project was done via a cluster randomised controlled trials in which clubs were randomised to participate in the study. The aim was for the sample demographics to reflect the demographics indicative of those playing grassroots football in the Valencian Community.

\section{Measures}

Multidimensional Inventory of Perfectionism in Sport. To measure striving for perfection and negative reactions to imperfection in young footballers we used the short form of the Multidimensional Inventory of Perfectionism in Sport (MIPS; Stoeber et al., 2007) comprising five items that capture negative reactions 


\section{Validation of Spanish MIPS in young footballers}

to imperfection (NRI) (e.g., "I feel extremely stressed if everything does not go perfectly") and five items measuring individual differences in striving for perfection (SP) (e.g., "I strive to be as perfect as possible"). The items were preceded by the stem "when playing or practicing football". Participants responded to the items on a scale ranging from $1=$ "never" to $6=$ "always". Evidence to support the validity and reliability of measurement associated with the scale has been provided in previous studies (e.g., Madigan et al., 2016; Stoeber and Becker, 2008; Stoeber et al., 2007; Stoeber et al., 2009).

Multidimensional Perfectionism Scale. Self-oriented and socially prescribed perfectionism were assessed using a brief version (Cox, Enns and Clara, 2002) of the Hewitt and Flett's (1991) Multidimensional Perfectionism Scale (MPS). The two subscales of the MPS contain 10-items in total measured on a sevenpoint Likert scale $(1=$ strongly disagree to $7=$ strongly agree). Responses on the self-oriented perfectionism subscale reflect excessive striving for high personal standards and self-critical tendencies (e.g., "I demand nothing less than perfection of myself'). In contrast, responses to the socially prescribed perfectionism subscale reflect the belief that significant others have exceedingly high standards and that acceptance is based on the attainment of those standards (e.g., "The people around me expect me to succeed at everything I do"). Evidence to support the validity and reliability of measurement associated with the scale has been provided by Cox et al. (2002).

Prior to the study, the MIPS and MPS were translated and back-translated into Spanish following the procedure reported by Duda et al. (2013). In the first step, two individual neutral translators who were bilingual translated the instruments from English to Spanish. Next, back-translations were conducted by a new set of translators who were not involved in the original translation from English to Spanish. A careful comparison of the back-translations was carried out by a fourth individual. His/her goal was to establish the accuracy of the translation and identify whether any word or phrase had been interpreted differently and/or any meaning had been lost or misconstrued after translation.

Sport Anxiety Scale-2. Anxiety was measured with the Spanish version (Ramis, Torregrosa, Viladrich and Cruz, 2010) for young athletes of the worry subscale of the Sport Anxiety Scale-2 (SAS-2; Smith, Smoll, Cumming and Grossbard, 2006). This subscale includes 5 items and was used to measure individual differences in the cognitive facet of anxiety (e.g., "I worry that I will not play well"). This construct involves concerns about performing poorly and the resulting negative consequences. Participants were asked to indicate how they generally felt during competitions/ games in the last 3-4 weeks and responded on a 5-point Likert scale ranging from $1=$ "strongly disagree" to $5=$ "strongly agree" The internal consistency of the scale has been provided by Ramis et al. (2010).

Contingent Self-worth in Sport Scale. Contingent selfworth was evaluated with the Spanish version (Fabra, 2017) of the Contingent Self-worth in Sport Scale (Reinboth and Duda, 2003). This unidimensional scale is composed by 6-item (e.g., "I need to do well in football in order to feel good about myself"). Participants were asked to indicate their degree of agreement with each item, thinking about their performance in football during the last 3-4 weeks. Responses were indicated on a 5-point Likert scale anchored by strongly disagree (1) and strongly agree (5). The scale exhibited satisfactory internal consistency in previous work (Fabra, 2017; Reinboth and Duda, 2004).

\section{Procedure}

After selecting the teams randomly by area within the Valencian Community from the list of the Valencian Football Federation, we sent a letter to the sports director of the football club schools, informing them about the goals of the investigation and requesting their collaboration. All the schools contacted expressed interest in participating in the investigation. All participants and their parents were provided with verbal information about the investigation and completed an informed consent document before data collection. The questionnaires were completed by the players at the diverse football club schools during a 15-minute interval, before their normal training session. This research was conducted in accordance with international ethical guidelines, which are consistent with American Psychological Association guidelines.

Statistical and Psychometric Analysis 


\section{Atienza, Appleton, Hall, Castillo, Balaguer}

Prior to the main analyses, a missing value analysis was conducted on the data. Following this analysis, the data was then screened for univariate outliers. Distributions for all the variables were also assessed for normality.

All analyses were made with the total sample. The clubs were randomized reflecting the demographics indicative of those playing grassroots football in the Valencian Community. The sample of females obtained in the randomised controlled trial was too low (close to $10 \%$ of the total sample) to analyse the factorial invariance by gender of the MIPS. Give that the sample obtained in the present study reflects the gender of young footballers, we made the decision not to exclude the female football players.

The hypothesized factorial structure of the measures was tested using confirmatory factor analysis with LISREL 8.80 (Jöreskog and Sörbom, 2006). The model fit was evaluated using several indices: the raw and relative chi-square statistics, the non-normed fit index (NNFI), the comparative fit index (CFI) and the root mean square error of approximation (RMSEA). Models were considered to have adequate fit if the relative chi-square is less than 3 . With respect to the other indices, a NNFI and CFI greater than .90 suggests an acceptable fit of the data, while values higher that .95 indicate an excellent fit and a RMSEA close to .06 suggests a good fit. For reasons of brevity, the results of the CFAs, except for the MIPS, are not presented in the Results section, but they are available on request.

The internal consistency for the Spanish version of the MIPS in young footballers, the other subscales of perfectionism (self-oriented perfectionism and socially prescribed perfectionism scales), anxiety and contingent self-worth was analysed via Cronbach's alpha.

Bivariate and partial correlations were used to examine the relationships between the scales of the Spanish version of the MIPS in young footballers, self-oriented perfectionism and socially prescribed perfectionism subscales of the MPS, and maladaptive characteristics as anxiety and contingent self-worth.

\section{RESULTS}

\section{Preliminary analysis}

A missing value analysis was conducted on the data. Due to large amounts of missing data $(>5 \%), 10$ participants were removed from the sample. An inspection of the pattern of missing data suggested a non-systematic mechanism for the missing data. Consequently, the missing data was considered as missing at random and estimated using the Expectation Maximization Algorithm for LISREL and SPSS analysis purposes. In the analysis for univariate outliers (standardised z-scores larger than 3.29, $p$ $<.001$, two tailed), no outliers were found for MIPS, MPS, Anxiety and Contingent Self-worth items.

Analyses were based on 419 participants who had reasonably complete data for the MIPS, MPS, Anxiety, and Contingent Self-worth scales (i.e., they had missing values for no more than one item of the scales analysed).

The analysis of the normality distribution for the variables revealed moderate skewness and kurtosis in some items of the scales analysed. The univariate distributions of the items indicated that scores were non-normally distributed. Results showed negative skewness and negative kurtosis in some items. Kolmogorov-Smirnov test results also showed that scores were not normally distributed. Specifically, item 1 of MIPS ("I strive to be as perfect as possible") had higher values of skewness and kurtosis, as well as the highest mean and lower standard deviation, indicating that most football players showed high levels of striving to be as perfect as possible (see Table $1)$.

\section{Confirmatory factor analyses}

A polychoric correlation matrix and asymptotic covariance matrix were derived from data, and each model was estimated with the weighted least squares method. Since the scores were non-normally distributed, the weighted least squares method for model estimation was appropriate in present study.

Table 2 shows the fit indices corresponding to the models analysed. First we tested a unidimensional model. Acceptance of this model implies that the subscales from the MIPS are not measuring different 


\section{Validation of Spanish MIPS in young footballers}

constructs (Kenny, 1979). Secondly, we tested the two dimensional model proposed by the original authors of the MIPS (Stoeber et al., 2004; 2007).

The unidimensional model showed a $\chi^{2}=3.29$, suggesting a lack of fit, whereas both the NNFI and CFI suggested an acceptable fit with values of .91 and .93 , respectively. The RMSEA suggested an acceptable fit with values of .07 . The fit indices obtained for two-dimensional model showed a relative $\chi^{2}=2.46$, suggesting an adequate fit, and both the NNFI and CFI suggested a good and excellent fit with values of .95 and .96 , respectively. The RMSEA suggested a good fit with value of .06. Figure 1 show the two-dimensional model. For this model, all parameter estimates were statistically significant. As demonstrated in Figure 1, representing the standardized solution of the two dimensional model, the lowest factor loading and higher uniqueness is for the item 1.

Table 1

Descriptive statistics of the Spanish version of the Multidimensional Inventory of Perfectionism in Sport in young footballers

\begin{tabular}{|c|c|c|c|c|c|}
\hline Item & $M$ & $S D$ & Ske & Kur & $\mathrm{Z}_{\mathrm{K}-\mathrm{S}}$ \\
\hline \multicolumn{6}{|l|}{ Striving for perfection } \\
\hline 1. I strive to be as perfect as possible. & 5.17 & 1.31 & -1.62 & 1.85 & $.35^{* *}$ \\
\hline Me esfuerzo para ser tan perfecto/a como sea posible & & & & & \\
\hline $\begin{array}{l}\text { 3. It is important to me to be perfect in everything I attempt. } \\
\text { Para mí es importante ser perfecto/a en todo lo que intento hacer }\end{array}$ & 3.90 & 1.77 & -.31 & -1.23 & $.17^{* *}$ \\
\hline $\begin{array}{l}\text { 5. I feel the need to be perfect. } \\
\text { Tengo la necesidad de ser perfecto/a }\end{array}$ & 3.34 & 1.80 & .12 & -1.34 & $.15^{* *}$ \\
\hline $\begin{array}{l}\text { 7. I am a perfectionist as far as my targets are concerned. } \\
\text { Soy un/a perfeccionista en todo lo que tiene que ver conmigo }\end{array}$ & 3.46 & 1.77 & .02 & -1.26 & $.13^{* *}$ \\
\hline $\begin{array}{l}\text { 9. I have the wish to do everything perfectly. } \\
\text { Deseo hacerlo todo perfecto }\end{array}$ & 4.22 & 1.82 & -.59 & -1.07 & $.21 * *$ \\
\hline \multicolumn{6}{|l|}{ Negative reactions to imperfection } \\
\hline $\begin{array}{l}\text { 2. Ifeel extremely stressed if everything does not go perfectly. } \\
\text { Me estreso mucho si no me sale todo perfecto }\end{array}$ & 3.40 & 1.79 & .09 & -1.34 & $.15^{* *}$ \\
\hline $\begin{array}{l}\text { 4. I get completely furious if I make mistakes. } \\
\text { Me pongo muy furioso/a si cometo errores }\end{array}$ & 3.66 & 1.79 & -.00 & -1.33 & $.17^{* *}$ \\
\hline $\begin{array}{l}\text { 6. I get frustrated if I do not fulfil my high expectations. } \\
\text { Me frustro si no consigo mis altas aspiraciones }\end{array}$ & 3.46 & 1.75 & .07 & -1.25 & $.13^{* *}$ \\
\hline $\begin{array}{l}\text { 8. After participating in my sport I feel depressed if I have not been } \\
\text { perfect. } \\
\text { Me siento muy triste después de jugar o entrenar si no he estado } \\
\text { perfecto/a }\end{array}$ & 3.32 & 1.85 & .15 & -1.41 & $.16^{* *}$ \\
\hline $\begin{array}{l}\text { 10. If something does not go perfectly, I am dissatisfied with the whole } \\
\text { training session/competition/game. } \\
\text { Si hay algo que no sale perfecto, no me siento satisfecho/a con todo el } \\
\text { entrenamiento/partido }\end{array}$ & 3.57 & 1.82 & -.05 & 1.35 & $.14^{* *}$ \\
\hline
\end{tabular}

$* *=p<.01$. Ske $=$ Skewness; Kur $=$ Kurtosis 


\section{Atienza, Appleton, Hall, Castillo, Balaguer}

Table 2

Confirmatory factor analyses for the Spanish version of the Multidimensional Inventory of Perfectionism in Sport (MIPS) in young footballers

\begin{tabular}{llllllll}
\hline Model & $d f$ & $\chi^{2}$ & $\chi^{2 / d f}$ & RMSEA & $(90 \%$ CI $)$ & NNFI & CFI \\
\hline Unidimensional model & 35 & $115.22^{* *}$ & 3.29 & .07 & $(.059-.089)$ & .91 & .93 \\
Two dimensional model & 34 & $83.48^{* *}$ & 2.46 & .06 & $(.043-.075)$ & .95 & .96 \\
\hline
\end{tabular}

Note. $d f=$ degrees of freedom; $\chi^{2}=$ Chi-Square; RMSEA $=$ root mean square error of approximation; $90 \% \mathrm{CI}=90 \%$ confidence interval for the RMSEA; NNFI = non-normed fit index; CFI = comparative fit index.

$* *=p<.01$.

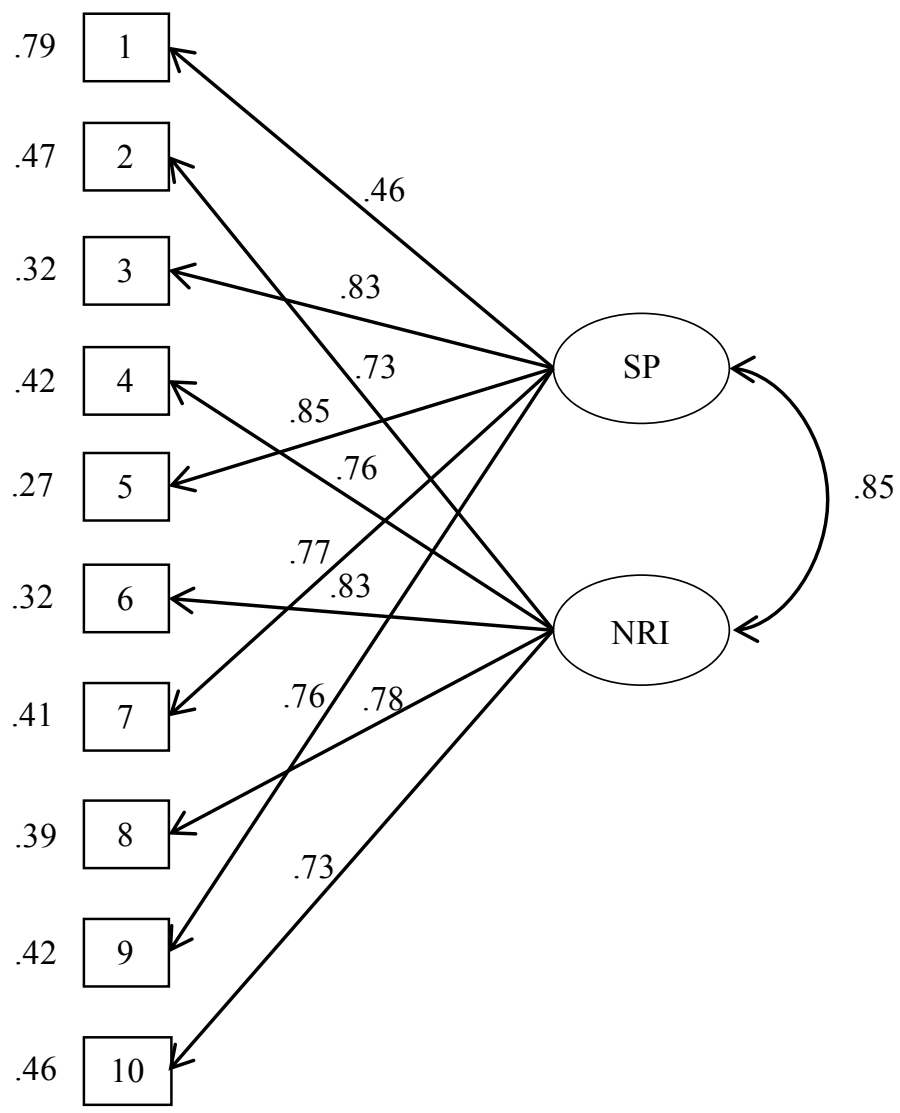

Figure 1. Factor loading, uniqueness and factor correlation for Model 2.

Note. All parameter estimates are standardized in relation to a common group metric, and all are statistically significant $(p$

$<.01) ; \mathrm{SP}=$ Striving for perfection; $\mathrm{NRI}=$ Negative reactions to imperfection.

\section{Internal consistency}

The analysis of the internal consistency for the Spanish version of the MIPS in young footballers, the other subscales of perfectionism of the MPS (selforiented perfectionism and socially prescribed perfectionism), anxiety and contingent self-worth showed Cronbach's alpha coefficients above .70 suggesting acceptable levels of internal reliability for each subscale/scale (see Table 3)

\section{Convergent validity}

The socially prescribed perfectionism subscale of MPS showed a large positive correlation with striving for perfection subscale and a moderate positive 


\section{Validation of Spanish MIPS in young footballers}

correlation with the negative reactions to imperfection subscale. The self-oriented perfectionism subscale of the MPS showed a large positive correlation with striving for perfection subscale and a moderate positive correlation with the negative reactions to imperfection subscale (see Table 3).

\section{Criterion Validity}

With respect to the relations between perfectionism and maladaptive variables, zero-order correlations (see Table 3) showed the following relations: striving for perfection had a low positive correlation with anxiety and positive moderate correlation with contingent self-worth. Likewise, the negative reactions to imperfection subscale showed a low positive correlation with anxiety and a large positive correlation with contingent self-worth. Finally, zeroorder correlations also showed a moderate positive correlation between anxiety and contingent self-worth.

Partial correlations (i.e., relationships with striving for perfection whilst controlling for negative reactions to imperfection and relationships with negative reactions to imperfection whilst controlling for striving for perfection) showed that striving for perfection was not related with anxiety or contingent self-worth. In contrast, negative reactions to imperfection were positively related with anxiety and contingent selfworth (see Table 3).

Table 3

Descriptive statistics, Cronbach's alphas, and correlations between perfectionism and maladaptive variables

\begin{tabular}{lllllllll}
\hline Variable & \multicolumn{9}{c}{ Bivariate Correlation } & \multicolumn{3}{c}{$\begin{array}{c}\text { Partial } \\
\text { Correlation }\end{array}$} \\
& 1 & 2 & 3 & 4 & 5 & 6 & 5 & 6 \\
\hline MIPS & & & & & & & .08 & .06 \\
1. Striving for perfection & .75 & & & & & & $.17^{* *}$ & $.47^{* *}$ \\
2. Negative reactions to imperfection & $.62^{* *}$ & .81 & & & & & \\
MPS & & & & & & & \\
3. Self-oriented perfectionism & $.67^{* *}$ & $.47^{* *}$ & .80 & & & & \\
4. Socially prescribed perfectionism & $.54^{* *}$ & $.55^{* *}$ & $.57^{* *}$ & .77 & & & \\
Maladaptive Outcomes & & & & & & & \\
5. Anxiety & $.24^{* *}$ & $.28^{* *}$ & $.23^{* *}$ & $.20^{* *}$ & .84 & & \\
6. Contingent self-worth & $.40^{* *}$ & $.59^{* *}$ & $.34^{* *}$ & $.54^{* *}$ & $.36^{* *}$ & .82 & \\
Mean & 4.02 & 3.48 & 4.95 & 3.78 & 3.83 & 2.89 & \\
$S D$ & 1.21 & 1.36 & 1.42 & 1.43 & 1.03 & 0.90 & \\
\hline
\end{tabular}

Note. MIPS = Multidimensional Inventory of Perfectionism in Sport; MPS = Multidimensional Perfectionism Scale; Bivariate correlation $=$ zero-order correlation; Partial correlation $=$ partial correlation between striving for perfection (negative reactions to imperfection) and maladaptive variables, controlling for the influence of negative reactions to imperfection (striving for perfection). Internal reliability coefficients are presented on the diagonal.

** $=p<.01$

\section{DISCUSSION AND CONCLUSION}

Three were the goals of the present study: First to examine the factor structure and internal reliability of striving for perfection and negative reactions to imperfection subscales from MIPS (Stoeber et al., 2007) translated into Spanish in young football players. A further goal was to provide initial evidence of validity of the Spanish MIPS in young footballers by examining of the associations with measures of contingent self-worth and cognitive anxiety, and two additional measures of perfectionism. And the third purpose was to determine the convergent validity by examining the association between the two subscales captured by the Spanish MIPS in young footballers and other perfectionism dimensions (i.e., self-oriented and socially prescribed perfectionism).

Results from confirmatory factor analyses suggested better fit for a two-dimensional compared to a unidimensional model of the Spanish MIPS in young footballers. The findings from the confirmatory factor analyses are consistent with those recently reported by Madigan (2016) in a sample of University athletes, and also by the ones offered by Pineda-Espejel et al. (2017) in a sample of elite Latino American athletes' 


\section{Atienza, Appleton, Hall, Castillo, Balaguer}

participating in a competition, providing additional evidence that the factor structure of the Spanish version of the MIPS replicates the original model proposed by Stoeber and colleagues (Stoeber et al., 2007). Furthermore, the current findings provide initial evidence regarding adequate internal consistency of the two subscales from the Spanish version of the MIPS in a sample of young footballers. Since in the study by Pineda et al (2017) the objective was to analyse perfectionism centered on competition (items preceded by the stem "during competition") and in the present study we were interested in including the analysis of perfectionism both in training and competition (items preceded by the stem "when playing or practicing football"), it should be noted that both cases, the factor structure obtained supports the original model of striving for perfection and negative reactions to imperfection factors proposed by Stoeber and colleagues (2007).

Regarding the criterion validity of the Spanish MIPS in young footballers, correlation analyses revealed athletes' scores on the striving for perfection subscale were positively and significantly associated with contingent self-worth and anxiety at the bivariate level. A positive association between striving for perfection and contingent self-worth and anxiety has been reported elsewhere in the perfectionism literature (e.g., Hill, Hall and Appleton, 2010; Gotwals et al., 2012; Pineda-Espejel et al., 2017) and our findings lend further support to Hill, Mallinson-Howard and Jowett (2018) recent conclusion in their meta-analysis study that, although perfectionistic striving may have motivational qualities that enhance performance, it can also render athletes susceptible to motivational and psychological problems. Likewise, the finding that both associations became non-significant (albeit still remained positive) in the partial correlations provide support to the hypothesis that overlap between the two MIPS subscales would inflate the positive relationships between striving for perfection and maladaptive characteristics and complement the findings of Hill and colleagues' meta-analyses, suggesting that residual striving for perfection is more positive for indicators of young athletes' health and well-being than perfectionistic striving, in this case Spanish young footballers.

Regarding the negative reactions to imperfection subscale, correlations with athletes' contingent self- worth and anxiety scores were generally consistent at the bivariate and partial level; that is, the associations were positive and significant (albeit slightly weaker correlations were reported at the partial level). These findings are consistent with a main assumption of the theoretical model underpinning the scale (Gotwals et al., 2012) and provide initial evidence that, as expected, negative reactions to imperfection and residual negative reactions to imperfection scores as measured by the Spanish MIPS in young footballers are related to a low sense of self-value and worries regarding performance in young footballers.

The analysis of the criterion related validity provides some interesting results regarding the Spanish version of MIPS in young footballers. A considerable overlap between the two perfectionism dimensions from the Spanish MIPS in young footballers was evident. This substantial construct overlap between striving for perfection and negative reactions to imperfection has been reported elsewhere in sport psychology research (see Hill et al., 2018), and further reinforces the importance of controlling for their overlap when researchers are interested in examining the unique relationship between each subscale and criterion variables (Stoeber, 2011). Bivariate correlations also revealed positive and significant correlations between the striving for perfection and negative reactions to imperfection with self-oriented and socially prescribed perfectionism, providing initial support the convergent validity of the Spanish MIPS in young footballers.

Several strengths and limitations of this study are worth noting. Strength includes providing additional empirical evidence about the MIPS subscale structure and composition, validating a Spanish version of MIPS suitable for use with youth Spanish footballers. On a practical level, the availability of a validated instrument of perfectionism for use with Spanish youth athletes will allow to advance in knowledge of this complex personality characteristics as well as the relationship between perfectionism and youth athletes' well-and ill-being. A knowledge that is necessary for the development of strategies to improve the quality of the sport experience of young athletes. Limitations includes that the sample was predominantly male $(87.8 \%)$. The gender of the sample is a biggest limitation. The results recently obtained by Pineda-Espejel et al. (2017) showing not 


\section{Validation of Spanish MIPS in young footballers}

invariance of intercepts, suggest that the responses of men and women in this instrument are not directly comparable. The sample of females obtained in the present study was too low to analyse the factorial invariance by gender of our Spanish version of the MIPS in young footballers. Thus, the findings should be taken with caution and further research is needed to evaluate the generalizability of the current. Another study limitation is the cross-sectional design that provides information on the relationships at a specific point of time and no indication of sequence of events in the relation between perfectionism and maladaptive characteristics. Future work may wish to use the Spanish version of the MIPS in young footballers to examine the influence of striving for perfection and negative reactions to imperfection overtime in other sport modalities.

Despite these limitations, the results of this study suggest that the Spanish version of the MIPS validated in young footballers is a well-adapted, reliable and valid sport specific instrument.

\section{REFERENCES}

1. Cox, B. J., Enns, M. W. and Clara, I. P. (2002). The multidimensional structure of perfectionism in clinically distressed and college student samples. Psychological Assessment, 14, 365-373. Doi: 10.1037/1040-3590.14.3.365

2. Duda, J. L., Quested, E., Haug, E., Samdal, O., Wold, B., Balaguer, I., ...Cruz, J. (2013). Promoting adolescent health through and intervention aimed at improving the quality of their Participation in Physical Activity (PAPA): Background to the project and main trial protocol. International Journal of Sport and Exercise Psychology, 11, 319-327. Doi: 10.1080/1612197X.2013.839413

3. Dunn, J. G., Gotwals, J. K. and Dunn, J. C. (2005). An examination of the domain specificity of perfectionism among intercollegiate studentathletes. Personality and Individual Differences, 38, 1439-1448. Doi: 10.1016/j.paid.2004.09.009

4. Fabra, P. (2017). Predicción de la intención de abandono en futbolistas adolescentes desde la teoría de las metas de logro y la teoría de la autodeterminación [Prediction of the intention of abandonment in adolescent soccer players from the theory of achievement goals and the theory of self-determination]. Doctoral dissertation, Universitat de València.

5. Flett, G. L. and Hewitt, P. L. (2002). Perfectionism and maladjustment: An overview of theoretical, definitional, and treatment issues. In P. L. Hewitt and G. L. Flett (Eds.), Perfectionism: Theory, research, and treatment (pp. 5-31). Washington, DC: American Psychological Association.

6. Frost, R. O., Marten, P., Lahart, C. and Rosenblate, R. (1990). The dimensions of perfectionism. Cognitive Therapy and Research, 14, 449-468. Doi: 10.1007/BF01172967

7. García-Naveira, A. (2018). Past, present and future of the sports psychologist in Spanish football. Revista de Psicología Aplicada al Deporte y al Ejercicio Físico, 3, 1-15. Doi: 10.5093/rpadef $2018 \mathrm{a} 8$

8. González-Hernández, J., Capilla Díaz, C., and Gómez-López, M. (2019). Impulsiveness and cognitive patterns. Understanding the perfectionistic responses in Spanish competitive junior athletes. Frontiers in Psychology, 10, 1605. doi: 10.3389/fpsyg.2019.01605

9. Gotwals, J. K., Stoeber, J., Dunn, J. G. and Stoll, O. (2012). Are perfectionistic strivings in sport adaptive? A systematic review of confirmatory, contradictory, and mixed evidence. Canadian Psychology/Psychologie Canadienne, 53, 263279. Doi: $10.1037 / \mathrm{a} 0030288$

10. Haraldsen, H. M., Halvari, H., Solstad, B. E., Abrahamsen, F. E., and Nordin-Bates, S. M. (2019). The role of perfectionism and controlling conditions in Norwegian elite junior performers' motivational processes. Frontiers in Psychology, 10, 1366 .

11. Hewitt, P. L. and Flett, G. L. (1991). Perfectionism in the self and social contexts: conceptualization, assessment, and association with psychopathology. Journal of Personality and Social Psychology, 60, 456-470. Doi: 10.1037/0022-3514.60.3.456

12. Hill, A. P., and Curran, T. (2016). Multidimensional perfectionism and burnout: A meta-analysis. Personality and Social Psychology 


\section{Atienza, Appleton, Hall, Castillo, Balaguer}

Review, 20, 269-288. Doi: $10.1177 / 1088868315596286$

13. Hill, A. P., Hall, H. K. and Appleton, P. R. (2010). Perfectionism and athlete burnout in junior elite athletes: The mediating role of coping tendencies. Anxiety, Stress, and Coping, 23, 415-430. Doi: 10.1080/10615800903330966

14. Hill, R. W., Huelsman, T. J., Furr, R. M., Kibler, J., Vicente, B. B. and Kennedy, C. (2004). A new measure of perfectionism: The Perfectionism Inventory. Journal of Personality Assessment, 82, 80-91. Doi: 10.1207/s15327752jpa8201_13

15. Hill, A. P., Mallinson-Howard, S. H. and Jowett, G. E. (2018). Perfectionism in sport: A metaanalytical review. Sport, Exercise, and Performance Psychology, 7, 235-270. Doi: $10.1037 /$ spy0000125

16. Hill, A. P., Mallinson-Howard, S. H., Madigan, D. J. and Jowett, G. E. (2019). Perfectionism in sport, dance, and exercise: An extended review and reanalysis. In G. Tenenbaum and R. C. Eklund (Eds.), Handbook of Sport Psychology. Hoboken, NJ: Wiley.

17. Jöresbog, K. G. and Sörbom, D. (2006). LISREL 8.80: A guide to the program and applications. Chicago, IL: SPSS, Inc.

18. Kenny, D.A. (1979). Correlations and causality. New York, NY: Wiley.

19. Madigan, D. J. (2016). Confirmatory factor analysis of the Multidimensional Inventory of Perfectionism in Sport. Psychology of Sport and Exercise, 26, 48-51. Doi: 10.1016/j.psychsport.2016.06.003

20. Madigan, D. J., Stoeber, J. and Passfield, L. (2016). Perfectionism and attitudes towards doping in junior athletes. Journal of Sports Sciences, 34, 700-706. Doi: 10.1080/02640414.2015.1068441

21. Madigan, D. J., Stoeber, J., and Passfield, L. (2017). Perfectionism and achievement goals revisited: The 3 x 2 achievement goal framework. Psychology of Sport and Exercise, 25, 120-124. Doi: $10.1016 /$ j.psychsport.2016.10.008

22. Mautz, C. P., Hill, R. W., Hueslman, T. J., and Bazzini, D. G. (2017). Behavioral activation and behavioral inhibition predict perfectionism.
Psychology and Behavioral Sciences, 6, 59-64. Doi: $10.11648 /$ j.pbs.20170604.13

23. Peris, D. (2018). Editorial Monográfico: Psicología del deporte aplicada al fútbol en España [Monographic Editorial: Psychology of sport applied to football in Spain]. Revista de Psicología Aplicada al Deporte y al Ejercicio Físico, 3, 1-2. Doi: 10.5093/rpadef2018a9

24. Pineda-Espejel, A., Alarcón, E. I., López-Walle, J. M. and Tomás, I. (2017). Adaptación al español de la versión corta del Inventario de Perfeccionismo Multidimensional en el Deporte en competición [Adaptation to Spanish of the short version of Multidimensional Inventory of Perfectionism in Sport during competition]. Revista Iberoamericana de Diagnóstico $y$ Evaluación Psicológica, 43, 45-57. Doi: 10.21865/RIDEP43_45

25. Ramis, Y., Torregrosa, M., Viladrich, C. and Cruz, J. (2010). Adaptación y validación de la versión española de la Escala de Ansiedad Competitiva SAS-2 para deportistas de iniciación [Adaptation and validation of the Spanish version of the Sport Anxiety Scale SAS-2 for young athletes]. Psicothema, 22, 1004-1009.

26. Reinboth, M. and Duda, J. L. (2003). Development and preliminary validation of a contingent self-worth measure in sport. Unpublished manuscript.

27. Reinboth, M. and Duda, J. L. (2004). Motivational climate, perceived ability, and athletes' psychological and physical well-being. Sport Psychologist, 18, 237-251. Doi: 10.1123/tsp.18.3.237

28. Slaney, R. B., Rice, K. G., Mobley, M., Trippi, J. and Ashby, J. S. (2001). The revised almost perfect scale. Measurement and Evaluation in Counseling and Development, 34, 130-145. Doi: 10.1080/07481756.2002.12069030

29. Smith, R. E., Smoll, F. L., Cumming, S.P. and Grossbard, J. R. (2006). Measurement of multidimensional sport performance anxiety in children and adults: The sport anxiety scale- 2 . Journal of Sport and Exercise Psychology, 28, 479-501. Doi: 10.1123/jsep.28.4.479

30. Stoeber, J. (2011). The dual nature of perfectionism in sports: Relationships with 


\section{Validation of Spanish MIPS in young footballers}

emotion, motivation, and performance. International Review of Sport and Exercise Psychology, 4, 128-145. Doi: 10.1080/1750984X.2011.604789

31. Stoeber, J., and Becker, C. (2008). Perfectionism, achievement motives, and attribution of success and failure in female soccer players. International Journal of Psychology, 43, 980-987. Doi: 10.1080/00207590701403850

32. Stoeber, J. and Madigan, D. J. (2016). Measuring Perfectionism in sport, dance, and exercise: exercise: Review, critique, recommendations. In A. P. Hill (Ed.), The psychology of perfectionism in sport, dance and exercise (pp. 31-56). New York, NY: Routledge.

33. Stoeber, J. and Otto, K. (2006). Positive conceptions of perfectionism: Approaches, evidence, challenges. Personality and Social Psychology Review, 10, 295-319. Doi: 10.1207/s15327957pspr1004_2

34. Stoeber, J., Otto, K., Pescheck, E., Becker, C. and Stoll, O. (2007). Perfectionism and competitive anxiety in athletes: Differentiating striving for perfection and negative reactions to imperfection. Personality and Individual Differences, 42, 959969. Doi: 10.1016/j.paid.2006.09.006

35. Stoeber, J., Otto, K. and Stoll, O. (2004). Mehrdimensionales inventar zu perfektionismus im sport (MIPS) [Multidimensional inventory of perfectionism in sport (MIPS)]. In J. Stöber, K. Otto, E. Pescheck, and O. Stoll (Eds.), Skalendokumentation "Perfektionismus im Sport", 7, 4-13.

36. Stoeber, J., Stoll, O., Salmi, O. and Tiikkaja, J. (2009). Perfectionism and achievement goals in young Finnish ice-hockey players aspiring to make the Under-16 national team. Journal of Sports Sciences, 27, 85-94. Doi: $10.1080 / 02640410802448749$

37. Terry-Short, L. A., Owens, R. G., Slade, P. D. and Dewey, M. E. (1995). Positive and negative perfectionism. Personality and Individual Differences, 18, 663-668. Doi: 10.1016/01918869(94)00192-U 